\title{
Particle size for improvement of peptide production in mixed-culture solid-state fermentation of soybean meal and the corresponding kinetics
}

\author{
Junjun Guan", Guohao Yang, Haicheng Yin, Feng Jia, Jinshui Wang \\ College of Biological Engineering, Henan University of Technology, Lianhua Street, Zhengzhou New \& High-tech Industrial Development \\ Zone, Zhengzhou 450001, China
}

\section{Email address:}

junjunguan@163.com (Junjun Guan)

\section{To cite this article:}

Junjun Guan, Guohao Yang, Haicheng Yin, Feng Jia, Jinshui Wang. Particle Size for Improvement of Peptide Production in Mixed-Culture Solid-State Fermentation of Soybean Meal and the Corresponding Kinetics. American Journal of Agriculture and Forestry. Vol. 2, No. 1, 2014, pp. 1-6. doi: 10.11648/j.ajaf.20140201.11

\begin{abstract}
Experiments were undertaken to study particle size and its distribution for improvement of peptide production by mixed-culture (Bacillus sublitis, Saccharomyces sp. and Lactococcus lactis) solid-state fermentation (SSF) of soybean meal and the corresponding kinetics. A particle size of 1-1.4mm of soybean meal gave the highest finial peptide yield, and as the proportion of $1-1.4 \mathrm{~mm} / 1-2 \mathrm{~mm}$ in natural soybean meal up to $61.30 \% / 58.58 \%$, the distribution of particle size was also appropriate for peptide production. Logistic model fitted the data most accurately and could be used for growth kinetic profiles during the course of fermentation, and the higher growth rate was calculated for the substrate with optimal particle size distribution. Hence the mechanism could be inferred that appropriate particle size did improve the according rate of microbial growth, thus leading to the higher peptide yield in soybean meal SSF within a limited fermentation time.
\end{abstract}

Keywords: Particle Size, Peptide, Soybean Meal, Kinetics, Solid-State Fermentation

\section{Introduction}

The need for animal feed will inevitably increase in the future. As a main protein source for animal feedstuffs, soybean meal often has several antinutritional factors including carbohydrates [1], and antigenic proteins [2], which might cause hypersensitivity. Microbial fermentation $[3,4]$ is a more economical approach to reduce the antinutritional factors of soybean meal, and the use of different strains for soybean meal fermentation, not only can produce microbial enzymes to reduce anti-nutritional factors in soybean meal, but also can accumulate some other beneficial metabolites such as peptides that exert specific positive effects on cultured animal cells [5]. Therefore, improvement of peptide production from soybean meal fermentation will provide a higher nutritional value for animal growth and also be interested by more and more researchers now.

Solid-state fermentation (SSF) is often used to process soybean meal for the lower cost of production. In SSF process, the moist solid substrate is used and without free-flowing water, and thus the adherence and penetration of microorganisms are clearly associated with the physical properties of the substrate such as the crystalline or amorphous nature, the accessible area, surface area, porosity, particle size, etc. In all the above factors, particle size should play a major role due to the dependence of other factors on it [6]. Hence it is of interest to know how particle size affects the production based on the substrate availability during SSF. The effect of particle size on the growth and product formation in SSF was studied by many [7-9]. But until now almost no report has been available regarding the effects of the particle size and its distribution on the changes in the peptide production during mixed-culture SSF of soybean meal. Therefore an attempt was made in the present study, with particular reference to the effects of the particle size and its distriburtion on peptide production and growth profiles of soybean meal SSF.

\section{Materials and Methods}

\subsection{Microorganisms and Culture Preparation}

Bacillus sublitis (ACCC 01746), Saccharomyces sp. 
(CICIM Y0362) and Lactococcus lactis (ACCC 11092) were provided by Henan Engineering Laboratory for Collection and Selective Breeding of Industrial Microorganisms (Zhengzhou, China). The strains were cultured on nutrient agar (peptone beef extract agar) plates for Bacillus sublitis, potato dextrose agar plates for Saccharomyces sp., and MRS agar plates for Lactococcus lactis. The plates were incubated at $30{ }^{\circ} \mathrm{C}$ for $24 \mathrm{~h}$ for Bacillus sublitis and Saccharomyces sp. And 7 days for Lactococcus lactis until colonies produced, and were kept at $4{ }^{\circ} \mathrm{C}$ as cultures until use.

\subsection{Solid Substrate and Chemicals}

Soybean meal was produced by Henan Sunshine Oils and Fats Group (Zhengzhou, China), analysed for protein $(46 \%, \mathrm{~N} \times 6.25)$ by Kjedhal method, subjected to a sieving procedure using sieves mesh-size of 10, 14, 18, 40 and 80 , and classified into six different diameter sizes: $<0.18 \mathrm{~mm}(\mathrm{P} 1), \quad 0.18-0.425 \mathrm{~mm}(\mathrm{P} 2), \quad 0.425-1 \mathrm{~mm}(\mathrm{P} 3)$, $1-1.4 \mathrm{~mm}(\mathrm{P} 4), 1.4-2 \mathrm{~mm}(\mathrm{P} 5)$, and $>2 \mathrm{~mm}(\mathrm{P} 6)$, according to which of the sieves mesh-size that the soybean meal retained. The soybean meal without treatment of sieving procedure was called natural soybean meal and expressed by "natural" in this study. The soybean meal with different particle sizes and its natural were used alone or in combination as solid substrates. All chemicals and medium ingredients were purchased from Shanghai Chemical Co. (Shanghai, China).

\subsection{Solid-State Fermentation (SSF)}

Two culture loops of Bacillus sublitis (B), Saccharomyces sp. (S) and Lactococcus lactis (S) were respectively transferred to $250 \mathrm{~mL}$ conical flasks containing $50 \mathrm{~mL}$ of liquid soybean meal dextrose medium made of $4 \%$ soybean-meal powder (particle size $<0.15 \mathrm{~mm}$, passing through 100-mesh screen) and 1\% dextrose, in order to adapt the strains for the solid substrate. The flasks were shaken at $150 \mathrm{rpm}$ for Bacillus sublitis and statically placed for Lactococcus lactis and Saccharomyces sp. At $30{ }^{\circ} \mathrm{C}$ for $8 \mathrm{~h}$. The solution was used as a stock solution for SSF.

A 250-mL conical flask, which was capped with rubber stopper perforated with a syringe needle for gas release, was used for SSF. A total inoculum of $10 \%(\mathrm{v} / \mathrm{w})$ was used to inoculate $50 \mathrm{~g}$ of substrate with the inoculation ratio of $\mathrm{B}: \mathrm{S}: \mathrm{L}=1: 1: 1(\mathrm{v}: \mathrm{v}: \mathrm{v})$. Solid substrate with an original moisture content of $12 \%$ was adjusted to a moisture content of $50 \%$ by using distilled water, and the initial $\mathrm{pH}$ was maintained at a natural level as reported [15] and actually tested at $6.8 \pm 0.1$ in this study. No nutrients or minerals were added to the substrate, due to soybean meal as the natural medium that contains the organic carbon, nitrogen, phosphorus, vitamins and metal ions to allow microbial growth, and the case that a supplement such as wheat bran might relatively reduce the total content of protein in soybean meal owing to the lower content of protein in supplement and thus would affect the nutrient value for application in animal feed. In addition, for this scheme the effect of particle size of soybean meal on the SSF could be investigated clearly without the interference of the supplement. The substrate was sterilized at $121{ }^{\circ} \mathrm{C}$ and 103 $\mathrm{kPa}$ in an autoclave for $20 \mathrm{~min}$. And, SSF was done by statically incubating the substrate at $30{ }^{\circ} \mathrm{C}$ in a thermostat incubator within a water reservoir to maintain the relative humidity and moisture level of the substrate, and the samples were withdrawn every $3 \mathrm{~h}$. Content of peptide of the fermented soybean meal was measured. All treatments were repeated three times.

\subsection{Peptide and Dry Matter Assays}

The peptide content in sample was determined by Lowry method [16]. $1 \mathrm{~g}$ sample was put into $50 \mathrm{~mL}$ of $15 \%(\mathrm{w} / \mathrm{w})$ TCA solution and stirred and incubated for $5 \mathrm{~min}$ at $25^{\circ} \mathrm{C}$, and then the mixture was filtered. After the filtrate was centrifuged at $4,000 \times \mathrm{g}$ for $30 \mathrm{~min}$, the obtained supernatant, containing peptide $(<10 \mathrm{kDa})$ from fermented soybean meal, could be analyzed by Lowry method. The content of small peptide, expressed as a percentage (dwb), was calculated by dividing the weight of TCA-soluble peptide by the dry matter mass in the original sample.

The dry matter mass was determined by weighing after oven-drying at $105^{\circ} \mathrm{C}$ overnight.

\subsection{Calculation}

The linear, exponential and logistic equations have typically been used to characterize growth profiles in SSF [17]. The integrated forms of these equations are expressed as follows:

linear,

$$
X=K t+X_{0}
$$

exponential,

$$
X=X_{0} e^{\mu t}
$$

and logistic,

$$
X=\frac{X_{m}}{1+\left(\frac{X_{m}}{X_{0}}-1\right) e^{-\mu t}}
$$

in which, $X$, biomass concentration; $X_{0}, X$ at time $0 ; t$, fermentation time; $K$, growth rate; $\mu$, constant of growth rate; $X_{m}$, carrying capacity. For the measurement of biomass $(X)$ in the construction of growth profiles, some different units have been used by researchers [17], and in this study the content of peptide (dwb), produced by microorganisms in SSF, was used for the growth profile, due to the purpose of this study, relation of peptide production and particle size distribution, which could also reflect the microbial growth indirectly.

For the logistic equation, the maximum growth rate $(d X / d t)$ can be obtained through the second derivative of Eq. (3) at, 


$$
\frac{d^{2} X}{d t^{2}}=0
$$

and the solution to this equation is,

$$
t_{X_{m} / 2}=\frac{\ln \left(\frac{X_{m}}{X_{0}}-1\right)}{\mu}
$$

at which, $X=X_{m} / 2$. The point $\left(t_{X m / 2}, X_{\mathrm{m}} / 2\right)$ is the inflexion of the Eq. (3) for a sigmoidal curve, where the maximum rate occurred.

Eqs. (1) - (3) were fitted to triplicate sets of data using linear and non-linear regression modules of the software, Polymath (Version 6.0, USA). The correlation coefficients $\mathrm{R}^{2}$ were used to judge whether the equation represents correctly the data and for comparing various equations representing the same dependent variable. The goodness of fit was evaluated with the root-mean-square deviation (Rmsd).

\subsection{Statistical Analysis}

Analysis of variance (ANOVA) and least significant difference (LSD) were used in order to determine the differences among treatments $(\mathrm{P}<0.05)$ by SAS (version 9.1).

\section{Results and Discussion}

\subsection{Effect of Particle Size of Substrate on the Peptide Vield of Soybean Meal SSF}

During SSF process, the availability of surface area plays an important role in microbial attachment, mass transfer, subsequent microbial growth and metabolite production, and is most associated with the particle size of the substrate [10]. To study the effect of the particle size of substrate on the peptide yield in SSF of soybean meal for $36 \mathrm{~h}$, different particle sizes $(<0.18 \mathrm{~mm}, \quad 0.18-0.425 \mathrm{~mm}, \quad 0.425-1 \mathrm{~mm}$, $1-1.4 \mathrm{~mm}, 1.4-2 \mathrm{~mm},>2 \mathrm{~mm}$, and natural) were used in the cultivation and the results are shown in Figure 1. The maximum of peptide content $(\mathrm{P}<0.05)$ was obtained on the soybean meal with particle size of $1-1.4 \mathrm{~mm}$. An increase or decrease in the particle size led to reduction of peptide yield, but no significant difference $(\mathrm{P}>0.05)$ was found between particle sizes of $1-1.4 \mathrm{~mm}$ and $1.4-2 \mathrm{~mm}$, and between particle sizes of $0.425-1 \mathrm{~mm}$ and $>2 \mathrm{~mm}$. Fermentation of the fine $(<0.425 \mathrm{~mm})$ soybean meal resulted in significantly lower content $(\mathrm{P}<0.05)$ of peptide. Moreover, it was interesting that SSF with natural substrate had a high yield of peptide, only lower than treatments with particle sizes of $1-1.4 \mathrm{~mm}$ and $1.4-2 \mathrm{~mm}$ (Figure 1), which should be related to its high content $(42 \%)$ of particle size of 1-2mm (Table 1) and would be concerned with particle size distribution of mixture.

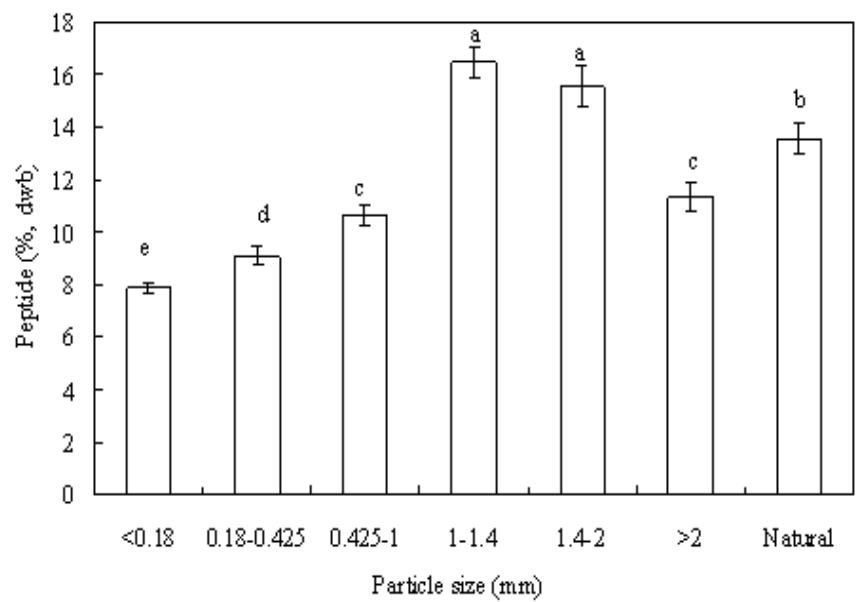

Figure 1. Effect of particle sizes on peptide contents in mixed-culture SSF of soybean meal for a fermentation time of 36h. $N=3$. Means followed by the same letter are not significantly different at $P=5 \% . L S D_{0.05}=0.9152$.

\begin{tabular}{|c|c|c|c|c|c|c|c|}
\hline \multirow{2}{*}{ Substrates } & \multicolumn{7}{|c|}{ Particle size distribution (\%) } \\
\hline & P1 & $\mathbf{P 2}$ & $\mathbf{P 3}$ & $\mathbf{P 4}$ & P5 & P6 & $1-2 m m$ \\
\hline Natural & 3.00 & 17.00 & 30.00 & 22.00 & 20.00 & 8.00 & 42.00 \\
\hline \multicolumn{8}{|c|}{ Natural + P4 (w: w) } \\
\hline M1(1:0.25) & 2.25 & 12.75 & 22.50 & 37.60 & 15.00 & 6.00 & 52.60 \\
\hline M2(1:0.5) & 2.00 & 11.30 & 20.00 & 48.00 & 13.30 & 5.30 & 61.30 \\
\hline M3(1:1) & 1.50 & 8.50 & 15.00 & 61.00 & 10.00 & 4.00 & 71.00 \\
\hline M4(1:2) & 1.00 & 5.70 & 10.00 & 74.00 & 6.70 & 2.70 & 80.70 \\
\hline \multicolumn{8}{|c|}{ Natural + P4 + P5 (w: w: w) } \\
\hline M5(1:0.1:0.1) & 2.50 & 14.17 & 25.00 & 26.66 & 25.00 & 6.67 & 51.66 \\
\hline $\mathrm{M} 6(1: 0.2: 0.2)$ & 2.14 & 12.14 & 21.43 & 30.00 & 28.58 & 5.71 & 58.58 \\
\hline M7(1:0.3:0.3) & 1.87 & 10.63 & 18.75 & 32.50 & 31.25 & 5.00 & 63.75 \\
\hline M8(1:0.5:0.5) & 1.50 & 8.50 & 15.00 & 36.00 & 35.00 & 4.00 & 71.00 \\
\hline
\end{tabular}

Table 1. Particle size distribution of different substrates. 


\subsection{Effect of Particle Size Distribution of Mixture on the Peptide Content during SSF of Soybean Meal}

Natural mixed with other substrates with some particle size was investigated during the course of SSF and the selection of supplement was based on the results of previous batches. Substrate of P4 (1-1.4mm) was hence chosen and P5 (1.4-2mm) was also considered for comparison. The particle size distributions of different mixtures are shown in Table 1, and effects of mixtures on changes of peptide content with fermentation time can be seen from Figure 2. The increase of proportion of P4 or $\mathrm{P} 4+\mathrm{P} 5$ in the mixture could enhance the final yield of peptide. For the total fermentation process, the yield of peptide increased significantly $(\mathrm{P}<0.05)$ as the proportion of $\mathrm{P} 4$ and $\mathrm{P} 4+\mathrm{P} 5$ was above $61.30 \%$ and $58.58 \%$ respectively, compared to natural. However, for the similar type treatments such as M1, M2, M3 and M4, when the proportion of $\mathrm{P} 4$ and $\mathrm{P}+\mathrm{P} 5$ was above $71.00 \%$ and $63.75 \%$ respectively, there was no significantly difference in peptide production between those mixtures (M3 and M4, M7 and M8) used as substrates. Moreover, no significantly difference between P4, M4 and M8, which indicated that the proportion of $\mathrm{P} 4$ and $\mathrm{P} 4+\mathrm{P} 5$ in mixture reaching $80.70 \%$ and $71.00 \%$ respectively had a similar peptide yield to substrate only with $1-1.4 \mathrm{~mm}$ particle size.

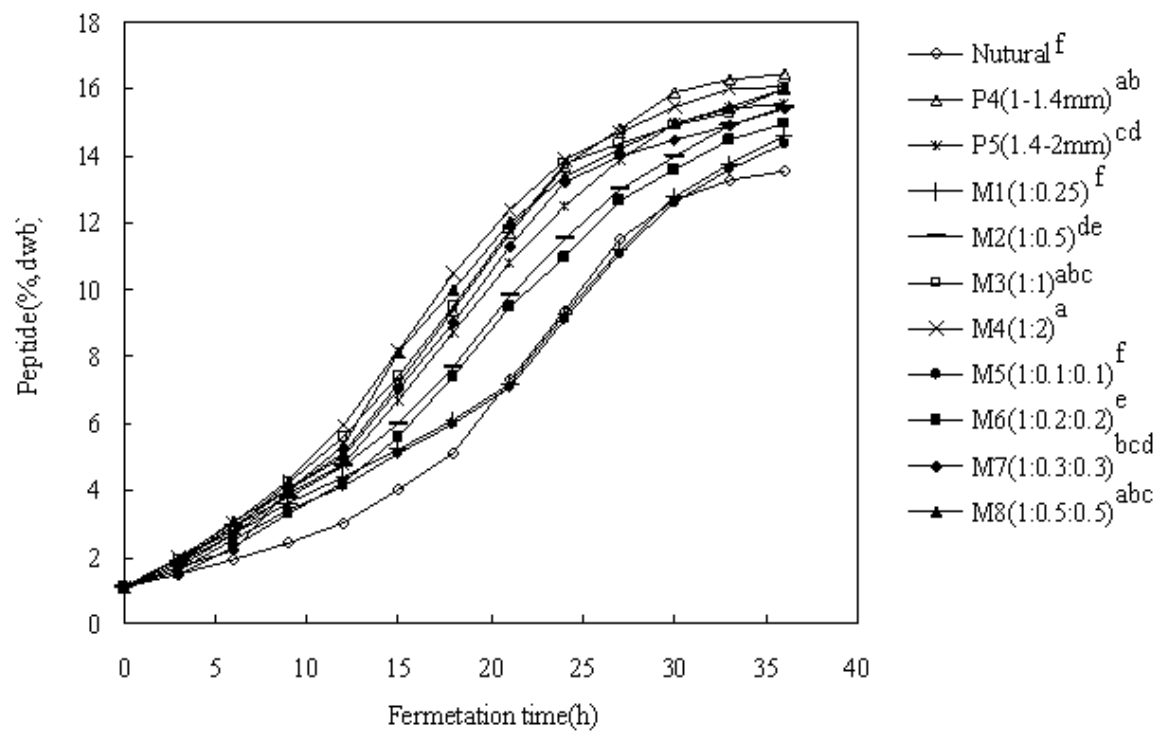

Figure 2. Time profiles of peptide content at different substrates during mixed-culture SSF of soybean meal. Different letters represent significant differences at $P=5 \%$. LSD0.05 $=0.562$. All different substrates are described in Table 1 .

\subsection{Growth Kinetic Profiles}

Table 2. Kinetic analysis of growth profiles using liner, exponential and logistic equation*

\begin{tabular}{|c|c|c|c|c|c|c|c|c|c|c|c|}
\hline \multirow{2}{*}{$\mathbf{S}$} & \multicolumn{3}{|l|}{ Linear } & \multicolumn{3}{|c|}{ Exponential } & \multicolumn{5}{|l|}{ Logistic } \\
\hline & $K\left(\% \cdot h^{-1}\right)$ & $\mathbf{R}^{2}$ & Rmsd & $\mu\left(h^{-1}\right)$ & $\mathbf{R}^{2}$ & Rmsd & $X_{m}(\%, \mathrm{dwb})$ & $\mu\left(h^{-1}\right)$ & $t_{X_{m} / 2}$ (h) & $\mathbf{R}^{2}$ & Rmsd \\
\hline $\mathrm{N}$ & 0.33 & 0.91 & 0.38 & 0.076 & 0.87 & 0.46 & $18.15 \mathrm{ab}$ & $0.11 \mathrm{e}$ & $24.9 \mathrm{a}$ & 0.985 & 0.160 \\
\hline P4 & 0.47 & 0.97 & 0.28 & 0.083 & 0.62 & 0.96 & 17.59abc & $0.16 \mathrm{bc}$ & $16.9 \mathrm{bcd}$ & 0.998 & 0.067 \\
\hline P5 & 0.43 & 0.97 & 0.25 & 0.081 & 0.66 & 0.86 & $16.82 \mathrm{abc}$ & $0.15 \mathrm{~cd}$ & $17.7 \mathrm{bc}$ & 0.998 & 0.057 \\
\hline M1 & 0.36 & 0.96 & 0.24 & 0.077 & 0.86 & 0.47 & $17.93 \mathrm{a}$ & $0.12 \mathrm{e}$ & $22.7 \mathrm{a}$ & 0.992 & 0.110 \\
\hline M2 & 0.41 & 0.98 & 0.21 & 0.080 & 0.73 & 0.71 & $16.88 \mathrm{abc}$ & $0.14 d$ & $19.0 \mathrm{~b}$ & 0.998 & 0.062 \\
\hline M3 & 0.45 & 0.97 & 0.27 & 0.082 & 0.56 & 0.98 & $16.46 \mathrm{bc}$ & $0.17 \mathrm{ab}$ & $15.5 \mathrm{~cd}$ & 0.998 & 0.070 \\
\hline M4 & 0.47 & 0.97 & 0.28 & 0.083 & 0.50 & 1.07 & $16.60 \mathrm{abc}$ & $0.18 \mathrm{a}$ & $14.7 \mathrm{~d}$ & 0.999 & 0.035 \\
\hline M5 & 0.35 & 0.96 & 0.27 & 0.077 & 0.87 & 0.45 & $17.96 \mathrm{a}$ & $0.12 \mathrm{e}$ & $22.4 \mathrm{a}$ & 0.995 & 0.090 \\
\hline M6 & 0.39 & 0.97 & 0.25 & 0.079 & 0.77 & 0.66 & $16.79 \mathrm{abc}$ & $0.14 d$ & $19.0 \mathrm{~b}$ & 0.999 & 0.049 \\
\hline M7 & 0.43 & 0.96 & 0.28 & 0.081 & 0.61 & 0.92 & $16.19 \mathrm{c}$ & $0.16 b c$ & $16.4 \mathrm{~cd}$ & 0.997 & 0.081 \\
\hline M8 & 0.46 & 0.97 & 0.26 & 0.082 & 0.54 & 1.00 & $16.34 \mathrm{c}$ & $0.17 \mathrm{ab}$ & $15.5 \mathrm{~d}$ & 0.998 & 0.061 \\
\hline
\end{tabular}

"S,Substrates; N,Natural; All different substrates are described in Table 1. Values followed by the same lowercase letter within a column are not significantly different at $\mathrm{P}=5 \%$. 
Growth kinetic profiles of different substrates including natural, substrate with single particle size, and mixture, were analyzed by fitting the data in Figure 2 to three empirical growth model (linear, exponential and logistic) and results shown in Table 2 . The higher $\mathrm{R}^{2}$ values were found in linear (0.91-0.97) and logistic (0.985-0.998) equations, indicating that these two models could represent correctly the data but logistic equation seemed to represent given sets of data much more correctly by further comparison. Therefore, exponential model would not be considered because the lower $\mathrm{R}^{2}$. Furthermore, the smallest Rmsd values (0.035-0.160) were found in logistic equation, also showing that this model fitted the data most accurately. So, logistic model would provide good answer for questions under investigation for mixed-culture SSF of soybean meal. This model fitting data from SSF with appropriate distribution of particle size (containing higher proportion of $1-1.4 \mathrm{~mm}$ or $1-2 \mathrm{~mm}$ ) of mixtures (M3, M4, M7 and M8) or $1.4 \mathrm{~mm}$ particle size of substrate had a smaller $X_{m}$ value and a higher $\mu$ value. On the other hand, as the proportion of P4 and P4+P5 was above $61.30 \%$ and $58.58 \%$ respectively, the growth rate constant $(\mu)$ increased significantly $(\mathrm{P}<0.05)$.

\subsection{Discussion}

It is known that the size of particle is directly associated with the specific surface area and porosity of the solid substrate. And in general, bigger particles, with less surface area, cause a trend towards poorer accessibility to the microorganism, but inter-particular porosity is greater, while smaller particles, with larger surface area, are preferred for better accessibility to the microorganism, but the porosity is less. These two opposing factors probably interact to determine the products corresponding to optimum microbial growth [11]. Furthermore, smaller particles are favorable for anaerobic fermentation, due to forming a higher solid medium density and a less void fraction. But, too small particles may diminish the heat transfer and carbon dioxide exchange rates because of medium compaction [12]. On the other hand, larger particles provide better aeration/respiration opportunities [13], which does encourage the growth of the aerobic organism. Thus, an appropriate particle size is required for a particular process in SSF [14]. In this study, three microorganisms were combination of aerobe (Bacillus sublitis) and facultative anaerobe (Saccharomyces sp. And Lactococcus lactis), and final results showed that appropriate particle size could make three microorganisms grow as quickly as possible, but otherwise microbial growth would be inhibited to some extent, thus leading to reduce the peptide yield. So, an optimal particle size of $1-1.4 \mathrm{~mm}$ should to be chosen for soybean meal SSF, which represented a compromise between the accessibility of nutrients and the availability of oxygen. In addition, particle size of $1.4-2 \mathrm{~mm}$ might be considered, mainly owing to no statistically significant difference with particle size of $1-1.4 \mathrm{~mm}$.

Results also suggested that the yield of peptide could be improved by adjusting the proportion of P4 (1-1.4mm) or P4+P5 (1-2mm) of natural substrate. But it was found that in the all process of SSF, P4 (1-1.4mm) treatment had overall higher peptide yield $(\mathrm{P}<0.05)$ than P5 $(1.4-2 \mathrm{~mm})$, other than previous batches, partly due to the different data obtained at fermentation time of $36 \mathrm{~h}$ and $0-36 \mathrm{~h}$, respectively, thus leading to the smaller value of $\mathrm{LSD}_{0.05}$ for comparison analysis of the latter, and this result also showed that the $1-1.4 \mathrm{~mm}$ was the optimal particle size of the substrate in practice for all process of soybean meal SSF. In addition, numerically, SSF with M4 seemed to produce higher yield of peptide than that with $\mathrm{P} 4$, although statistically, no significant difference between both substrates. And the reason for these results might need further study to investigate the relation between growth profiles and particle size distributions.

A smaller $X_{m}$ value and a higher $\mu$ value indicated a lower carrying capacity or biocapacity of substrate, which was the maximal load of substrate for peptide production and microbial growth that should be related to living environment, namely the particle size distribution in this study, and a higher growth rate, under those distributions. However, statistically, there was no significant difference between most $X_{\mathrm{m}}$ values obtained, partly due to a limited effect of particle size distribution on $X_{m}$ and maybe other factors needing further study. In addition, the increase of the growth rate constant $(\mu)$ implied that the particle size distribution affected growth rate significantly, which was also showed from the data of the time to maximal growth rate $\left(t_{X m / 2}\right)$ : less time for higher proportion of $\mathrm{P} 4$ and $\mathrm{P} 4+\mathrm{P} 5$ (Table 2). Therefore, the mechanism could be inferred that appropriate particle size could improve the corresponding rate of microbial growth.

\section{Conclusions}

In all, the optimal particle size of soybean meal for peptide production by SSF was $1-1.4 \mathrm{~mm}$, and when the proportion of $1-1.4 \mathrm{~mm} / 1-2 \mathrm{~mm}$ in natural soybean meal was increased to $61.30 \% / 58.58 \%$ or more, the distribution of particle size was also appropriate for peptide production. Logistic model fitted the data most accurately, and showed a higher growth rate for the substrate with optimal particle size distribution in SSF. Hence the mechanism could be inferred that appropriate particle size could improve the corresponding rate of microbial growth, thus causing an increase of peptide yield in soybean meal SSF within a limited fermentation time.

\section{Acknowledgements}

We are grateful to Zhengzhou Siwei Biotechnology Co., Ltd. For supplying the soybean meal sample. The results reported in this paper are from research carried out with 
financial support from Zhengzhou key scientific and technological project, no. 20120664, "Key technology of fermented soybean meal processed", and no. 121PCXTD518, "Technology innovation team of biotechnology and biomass resources transformation and security".

\section{References}

[1] Choct M, Dersjant-Li Y, McLeish J, Peisker M. "Soy oligosaccharides and soluble non-starch polysaccharides: a review of digestion, nutritive and anti-nutritive effects in pigs and poultry." Asian-Aust J Anim Sci, 23, pp. 1386-1398, 2010 .

[2] Song YS, Pérez VG, Pettigrew JE, Martinez-Villaluenga C, de Mejia EG. "Fermentation of soybean meal and its inclusion in diets for newly weaned pigs reduced diarrhea and measures of immunoreactivity in the plasma." Anim Feed Sc. Tech, 159, pp. 41-49, 2010.

[3] Hong K-J, Lee C-H, Kim SW: Aspergillus oryzae GB-107 fermentation improves nutritional quality of food soybeans and feed soybean meals. J Med Food 2004, 7: 430-435.

[4] Refstie S, Sahlström S, Bråthen E, "Baeverfjord G, Krogedal P: Lactic acid fermentation eliminates indigestible carbohydrates and antinutritional factors in soybean meal for Atlantic salmon (Salmo salar)." Aquaculture, 246, pp. 331-345, 2005.

[5] Franěk F, Hohenwarter O, Katinger H. "Plant Protein Hydrolysates: Preparation of Defined Peptide Fractions Promoting Growth and Production in Animal Cells Cultures." Biotechno Prog, 16, pp. 688-692, 2000.

[6] Ramana Murthy MV, Karanth NG, Raghava Rao KSMS: "Biochemical Engineering Aspects of Solid-State Fermentation. in: Advances in Applied Microbiology." Volume 38. Edited by Saul N, Allen IL. Academic Press; pp. 99-147, 1993.

[7] Dilipkumar M, Rajamohan N, Rajasimman M. "Inulinase production in a packed bed reactor by solid state fermentation.” Carbohydr Polym, 96, pp. 196-199, 2013.
[8] Smail T, Salhi O, Knapp JS. "Solid-state fermentation of carob pods by Aspergillus niger for protein production: effect of particle size." World J Microb Biot, 11, pp. 171-173, 1995.

[9] Zadrazil F, Puniya AK. "Studies on the effect of particle size on solid-state fermentation of sugarcane bagasse into animal feed using white-rot fungi." Bioresour Technol, 54, pp. 85-87, 1995.

[10] Prakasham RS, Rao CS, Sarma PN. "Green gram husk-an inexpensive substrate for alkaline protease production by Bacillus sp. in solid-state fermentation." Bioresour Technol, 97, pp. 1449-1454, 2006.

[11] Muniswaran PKA, Charyulu NCLN. "Solid substrate fermentation of coconut coir pith for cellulase production." Enzyme Microb Technol, 16, pp. 436-440, 1994.

[12] Molaverdi M, Karimi K, Khanahmadi M, Goshadrou A. "Enhanced sweet sorghum stalk to ethanol by fungus Mucor indicus using solid state fermentation followed by simultaneous saccharification and fermentation." Ind Crops Prod, 49, pp. 580-585, 2013.

[13] Pandey A. "Recent process developments in solid-state fermentation." Process Biochem, 27. pp. 109-117, 1992.

[14] Ellaiah P, Srinivasulu B, Adinarayana K. "Optimisation studies on neomycin production by a mutant strain of Streptomyces marinensis in solid state fermentation." Process Biochem, 39. pp. 529-534, 2004.

[15] Wang D, Guang X, Deng X, Wei Z, Ding Y. "Study on fermenting soybean meal by a multi-strain mixtur." Cereal Feed Ind, (4), pp. 36-39, 2011.

[16] Lowry OH, Rosebrough NJ, Farr AL, Randall RJ. "Protein measurement with the folin phenol reagent." J Biol Chem, 193, pp. 265-275, 1951.

[17] Viccini G, Mitchell DA, Boitl SD, Gern JC, Rosa ASD, Costa RM, Dalsenter FDH. "Analysis of growth kinetic profiles in solid-state fermentation." Food Technol Biotechnol, 39, pp. 271-294, 2001. 